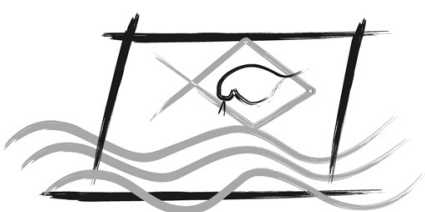

ECOTOX - BRASIL

\title{
Morpho-histochemistry analysis of freshwater planarians Girardia tigrina (Girard, 1850) exposed to sublethal concentrations of Malathion insecticide
}

\author{
Butturi-Gomes, D. ${ }^{1}$; Furquim, K.C.S. ${ }^{2}$; Carmargo-Matias, M.I. ${ }^{2} \&$ Marin-Morales, M.A. ${ }^{2}$ \\ ${ }^{1}$ Programa de Pós-Graduação em Estatística Aplicada e Biometria, Instituto de Ciências Exatas, Universidade Federal de Alfenas - Unifal. \\ Rua Gabriel Monteiro da Silva 700, CEP 37130-000, Alfenas, MG, Brazil. \\ ${ }^{2}$ Departamento de Biologia, Instituto de Biociências, Universidade Estadual Paulista "Júlio de Mesquita Filho" - UNESP. Av. 24-A 1515, \\ CEP 13506-900, Rio Claro, SP, Brazil.
}

(Received March 28, 2015; Accept August 03, 2016)

\begin{abstract}
Due to planarian regeneration capacity, researchers have made efforts in studying its gene regulation, cell and tissue responses. Despite such advances, many aspects of planarian biology and histology, especially for Girardia tigrina species, remain unknown. Thus, in this study, we aimed at analyzing the potencial of G. tigrina as a biological model for ecotoxicological research by firstly characterizing the morphology and histology of healthy individuals and then evaluating the sublethal effects of Malathion, a widely used insecticide in Brazil. We exposed individuals of $G$. tigrina to two sublethal concentrations of Malathion $\left(0.08 \mathrm{mg} \mathrm{L}^{-1}\right.$ and $\left.0.8 \mathrm{mg} \mathrm{L}^{-1}\right)$ insecticide for $96 \mathrm{~h}$, sectioned them, and then exposed the regenerating portions for another $72 \mathrm{~h}$. We submitted all material to scanning electron microscopy and to different histological/histochemical light microscopy techniques. Several changes in the treatment groups were present when compared to the control group. In external morphology, the following alterations were noteworthy: malformation and underdevelopment of the blastemas, pores dilation in the epidermis and loss of ventral cilia. Our main results regarding histology, histochemistry and cytochemistry were the disruption of several tissues, characterized by cytoplasmic changes, such as vacuolation, histochemical and nuclear changes, including chromatin marginalization. Thus, we concluded that Malathion, mainly in the lowest concentration tested, has acted on reproductive strategies of the tested organism, in addition to promoting necrosis in different tissues.
\end{abstract}

Keywords: Blastema, Cell death, Dugesiidae, Ecotoxicology, Necrosis, Organophosphate, Regeneration, Tissue damage.

\section{INTRODUCTION}

Freshwater planarians have been used as biomarkers for environmental contamination in several studies, including the works of Williams et al. (1986) and of Tehseen et al. (1992). More recently, these organisms have been of further interest as biological models for stem-cell differentiation, genotoxicity and teratogenicity studies, due to their strong regenerative potential (Guecheva et al., 2003; Knakievicz et al., 2008; Lowe et al., 2015; Ofoegbu et al., 2016). Planarian regeneration can be understood either as an asexual reproduction strategy or as a response to an injury (see Saló \& Agata (2012), for instance). Once the regeneration mechanism triggers (Witchley et al.,
2013), one can easily identify the development of a nonpigmented region, known as blastema. In fact, the blastema is rich in both differentiated and undifferentiated cells (i.e., neoblasts) (Saló \& Baguñà, 1986; Sánchez Alvarado, 2012).

Despite the advances in the field of planarian regeneration, most studies are focused in a specific species, Schmidtea mediterranea, partially neglecting other potentially informative biological models for ecotoxicological assessment. One of such species is Girardia tigrina, formerly Dugesia tigrina, a free-living, freshwater flatworm, which presents the advantage of both sexual and asexual reproduction and of relatively simple laboratory maintenance (Álvarez-Presas \& Riutort, 2014). 
As Knakievicz (2014) pointed out in a rather recent review, histo-cytopathological assays using G. tigrina is still a pending study. Thus, we aimed at both describing the main morphological and histochemical aspects of healthy individuals of said species and evaluating the sublethal effects of an overused insecticide, namely Malathion, whose mode of action is known to be the inhibition of acetylcholinesterase, mainly through dermic contact, disrupting the nervous system (USEPA, 2009). At this point, we understand it may be almost obnoxious to justify studies with pesticides and, thus, we refer to the early works of Parsons \& Witt (1989) and of Ongley (1996) for a general view of the effects of such chemicals in ecosystems and aquatic environments.

\section{MATERIAL AND METHODS}

In this study, we used the test organism Girardia tigrina (planarian), kept in breeding at Laboratório de Mutagênese, Departamento de Biologia, Instituto de Biociências/UNESP, Rio Claro, SP, Brazil. The specimens were fed twice a week with calf liver, which were acquired in local markets and were suitable for human consumption. For the development of the experiments, we selected adult individuals only (40-daysold and ranging from 12 to $15 \mathrm{~mm}$ in length). Our culture was continuously monitored with regard its sensitivity, both before and after our experiments, and had never presented any issues with mortality.

The Malathion insecticide (CAS \#12175-5) we used in the assays refers to the commercial product $50 \% \mathrm{EC}$ (emulsionable concentrate), manufactured in Brazil by Cheminova A/S. This product was banned in Europe, but it is still widely used in several yielded crops, livestock and in the urban environment of many countries, particularly those in South America. Malathion is a non-systemic organophosphate chemical, whose formula is O,O-dimethyl-S-(1,2-dicarboxyethyl)phosphorodithioate $\left(\mathrm{C}_{10} \mathrm{H}_{19} \mathrm{O}_{6} \mathrm{PS}_{2}\right)$ and, according to Howard (1991), Malathion is an insecticide that presents a potential risk when applied near aquatic environments, once it is highly toxic to freshwater invertebrates (see also PPDB (2016) for more up-to-date topics on toxicological aspects and properties of Malathion). For a broader view of organophosphates in the environment, we refer to the work of Vala Ragnarsdottir (2000).

We assessed two sublethal concentrations of the Malathion insecticide, 0.8 and $0.08 \mathrm{mg} \mathrm{L}^{-1}$, which were selected due to the results of prior, independent, both acute $(24 \mathrm{~h}, 48 \mathrm{~h}, 72 \mathrm{~h}$ ) and chronic (7 days), pilot assays. Following such results, we used the same temperature and light conditions, respectively $20^{\circ} \mathrm{C}$ and night simulation, within a BOD incubator.

In all treatment groups, we exposed the planarians for 96 hours to concentrations of Malathion. Our (negative) control group was composed by planarians of the breeding herd exposed to water samples (i.e., cultivation water). Then, we transversely sectioned all individuals in the prepharynx region using razor blades and returned them to their original group for another 72 hours.
In the sequence, we subjected all specimens to light microscopy and to scanning electron microscopy techniques (SEM). For each technique, we used 10 individuals, equally distributed in two replicates (half full vessels of $200 \mathrm{~mL}$ in total volume). All experiments followed a completely random design.

For SEM, we fixed the regenerating portions in Karnovsky mixture for $24 \mathrm{~h}$, dehydrated in $70 \%$ to $100 \%$ of alcohol series, followed by two baths in pure acetone for 15 minutes each. In order to complete dehydration process, we submitted the material to critical point drain. After dehydration, we deposited the material on aluminum brackets, subjected to gold sputtering, and we finally examined and photodocumented the resulting images of a scanning electron microscope (SEM 505).

In order to carry out the histological, histochemical and cytochemical techniques, we fixed the regenerating portions in paraformaldehyde (4\% in PBS) for 24 hours. Subsequently, we placed the samples in a sodium phosphate buffer $\mathrm{pH}$ 7.4 for another 24 hours. We then dehydrated the material in increasing concentrations of ethanol baths $(70 \%, 80 \%$, $90 \%$ and $95 \%$ ) for 15 minutes each. Finally, we embedded our material in resin (Leica), included, sectioned at $3 \mu \mathrm{m}$ of thickness, collected the slices on glass slides and proceeded according to each different technique.

For histological techniques, we stained the sections with hematoxylin (for 10 minutes) and eosin (for 7 minutes) (Junqueira \& Junqueira, 1983). We carried out the histochemical techniques: PAS/Alcian blue ( $\mathrm{pH}$ 2.5) staining (Junqueira \& Junqueira, 1983) used to detect acid and total polysaccharides; and PAS/bromphenol blue (Coello, 1989) to detect total polysaccharides and proteins. Lastly, we applied a cytochemical technique, known as Feulgen reaction, for DNA labeling (Feulgen \& Rossenbeck, 1924).

\section{RESULTS}

We split our results into short sections for easily referencing throughout the text. In the next subsections, we present the scanning electron microscopy and the light microscopy results, respectively.

\section{Scanning Electron Microscopy (SEM)}

In this section, we present the results for the control group and the treatment groups, firstly presenting the results for the blastema region and then for ventral and dorsal epidermal views.

We observed a well-developed blastema for the regenerating portions in the control group (Fig. 1A) and morphallaxis occurrence zones (Fig. 1B): differentiated cell migration formed a "bridging tissue", located over the gap between the blastema and the posterior portion of the body.

As expected, the ventral epidermis (Fig. 1C-D) of the planarian is a cilia-padded surface and, on the other hand, the dorsal epidermis to be a comparatively smooth surface (Fig. 1E). 
We noted severe deformation for the individuals exposed to $0.08 \mathrm{mg} \mathrm{L}^{-1}$ of Malathion, particularly in regions close gap structure (section) and the blastema (Fig. 1F-G). Furthermore, over-dilated pores in the ventral epidermis and complete absence of cilia (Fig. 1H).

The most notable alterations in the morphology of the individuals exposed to the other treatment group (i.e, 0.8 $\mathrm{mg} \mathrm{L}^{-1}$ of Malathion) were a significant reduction in the development and size of the blastema (Fig. 1I). Similar to the group exposed to $0.08 \mathrm{mg} \mathrm{L}^{-1}$, we observed absence of cilia as well (Fig. 1J-K).

\section{Light Microscopy}

We organized our histological results for the control group as follows: firstly, we present the results for the epidermis
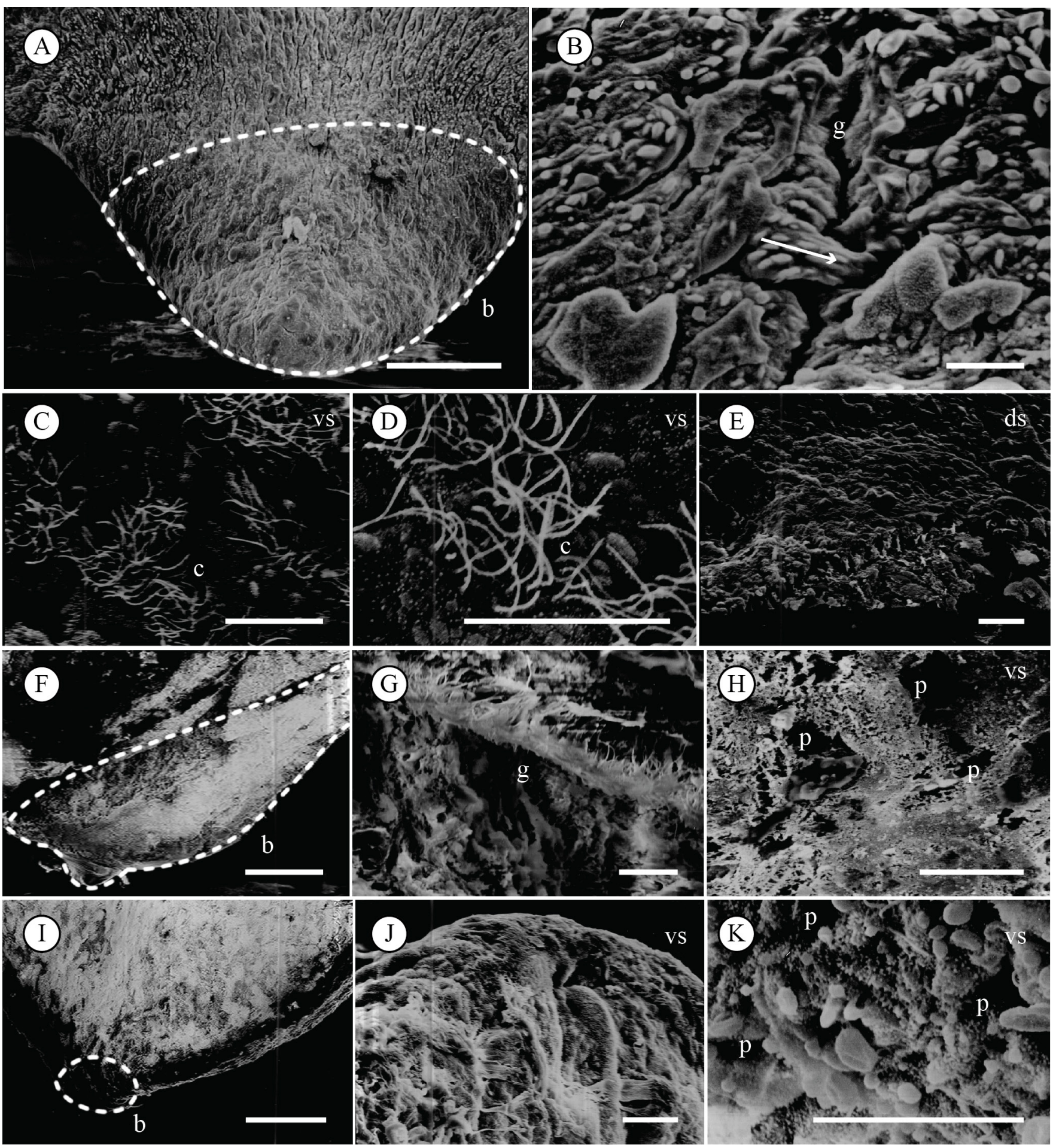

Figure 1. Scanning electron microscopy of planarians G. tigrina. A-E: control group; F-H: exposed group to $0.08 \mathrm{mg} \mathrm{L}^{-1}$ of Malathion insecticide; I-K exposed group to $0.8 \mathrm{mg} \mathrm{L}^{-1}$ of Malathion insecticide. $\mathrm{b}$ and dashed line: blastema region; g: gap; c: cilia; ds: dorsal surface; vs: ventral surface; arrow: "bridging tissue", connecting the posterior region of the body to the blastema, p: pores. Bars: A, F, I = $100 \mu \mathrm{m}$; B-E, G-H, J-K = $10 \mu \mathrm{m}$. 
and musculature, followed by the results for the parenchyma, nerve system and, finally, for the digestive tract. In sequence, we present the cytochemical results. The results of said techniques for the treatment groups are presented in a similar fashion, approaching the histochemical results for all groups at once in the end of this section.

The body surface of the specimens in the control group were covered by an epidermis, filled with secretory cells, known as rhabdites, and a thin layer of mucus, covering the whole body of the planarian. Right below the rhabdites, layers of cuboidal and elongated cells were observed (Fig. 2A).

Beneath the epidermal cells, we observed several bundles of longitudinal muscles and, in sequence, parenchyma. The latter is a tissue where two types of cells were predominant: fixed parenchyma cells (Fig. 2B) and goblet cells (Fig. 2C). We also found another, undifferentiated cell, the neoblast, which are responsible for cell replacement. The nerve bundles start from the head and are disposed through the whole body of the animal (Fig. 2D).
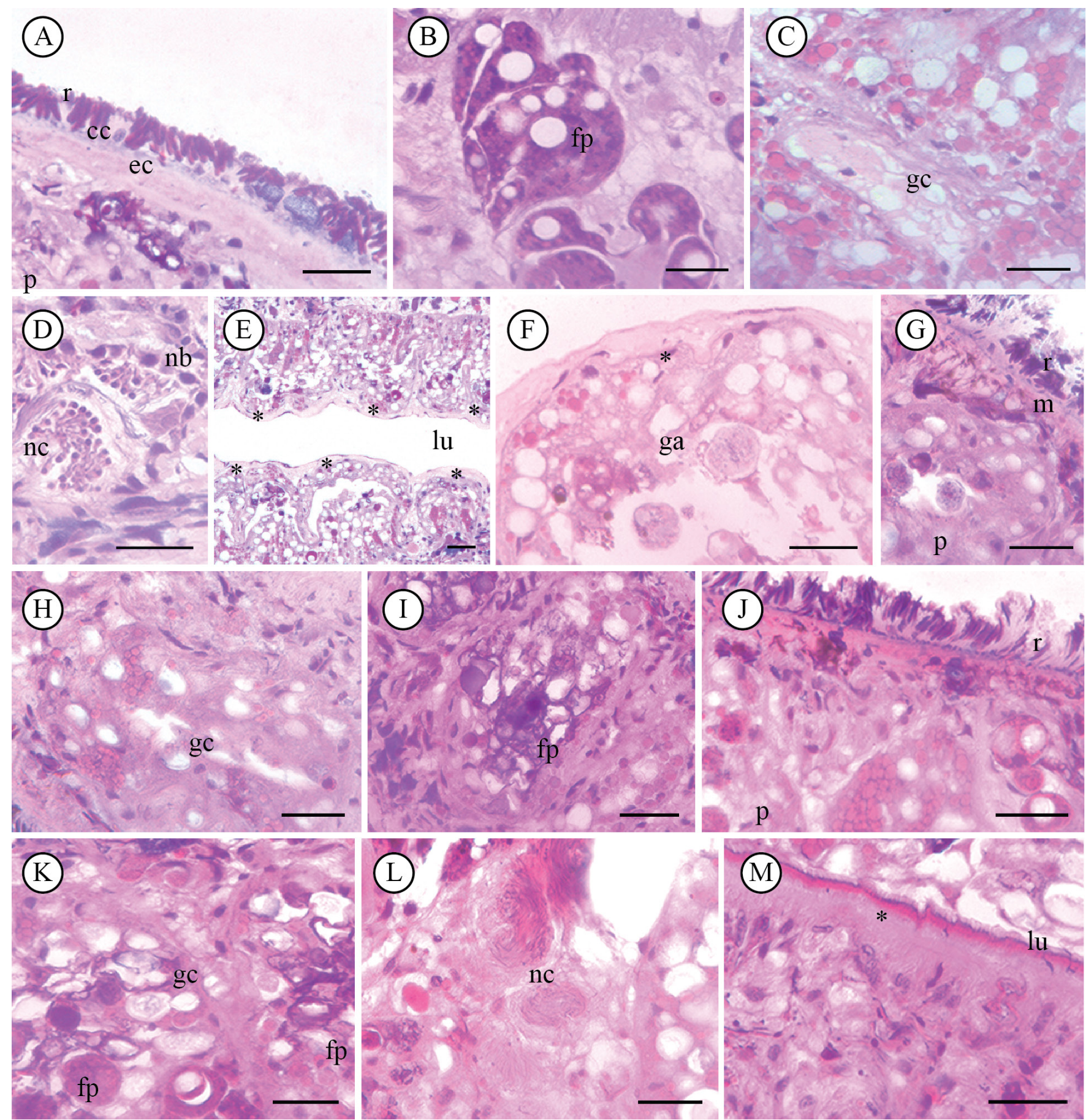

Figure 2. Histological sections of planarians G. tigrina stained by hematoxylin and eosin. A-F: control group; G-H: exposed group to $0.08 \mathrm{mg} \mathrm{L}{ }^{-1}$ of Malathion insecticide; J-M: exposed group to $0.8 \mathrm{mg} \mathrm{L}^{-1}$ of Malathion insecticide. cc: cuboidal cell; ec: elongated cell; ga: gastrodermal cell; gc: goblet cell; lu: lumen; m: muscles; nb: neoblasts; nc: nerve cords; fp: fixed parenchyma cells; pg: pigmentation cell; r: rhabdite. * cells facing the lumen. Bars: A-D,F-M $=300 \mu \mathrm{m} ; \mathrm{E}=500 \mu \mathrm{m}$. 
The fixed parenchymal cells have irregular shapes, with basophilic granules filling their cytoplasm. In the cytoplasm of said cells, there were structures larger than the granules, not marked by the applied staining techniques (Fig. 2B). The goblet cells have a thin layer of cytoplasm filled with granules not stained by neither hematoxylin nor eosin (Fig. 2C). The neoblasts are rounded cells, which possess a large nucleus immersed in a reduced cytoplasm (Fig. 2D). Also represented in Figure 2D, there were nerve bundles, corresponding to the extensions of the neurons present in the animals' heads. These bundles have two distinct regions, the central part, fairly stained by hematoxylin, and the peripheral part, mostly stained by eosin.
The digestive tract was another tissue we observed and, for the individuals in the control group, we could clearly identify two distinct layers of cells: (a) the layer facing the lumen, a thin structure, comprised by cells without any observable distinct bounds; and (b) a thick layer of secreting cells, namely gastrodermal cells. The latter have a half-moon shape and display a cytoplasm filled with basophilic and acidophilic granules, in addition to larger granules not stained by neither hematoxylin nor eosin (Fig. 2E-F).

In Figure 3, we observed different cell nuclei, belonging respectively to epidermis elongated and cuboidal cells (Fig. 3A-B), parenchyma cells (Fig. 3C-D) and the nerve cells (Fig.
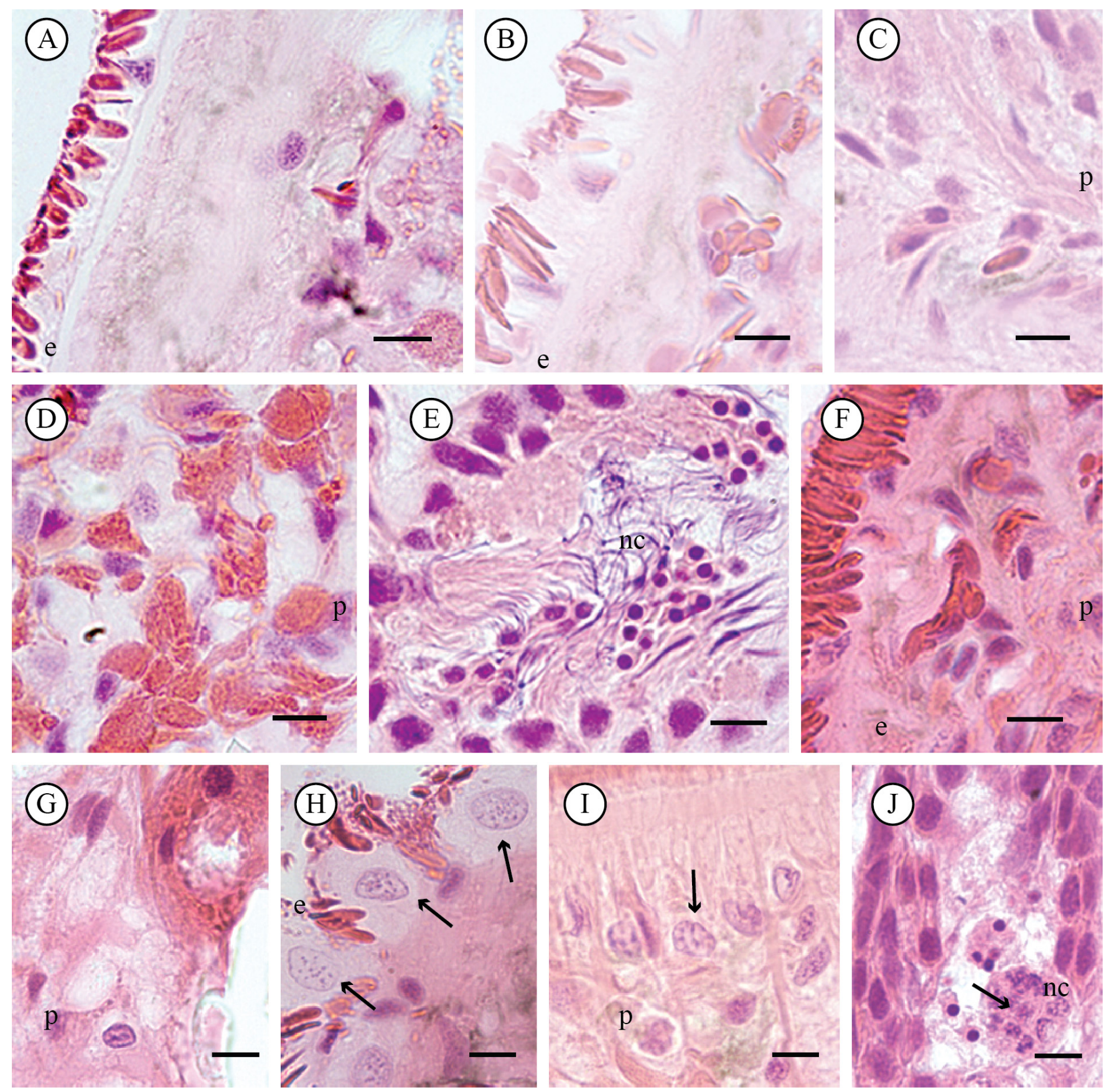

Figure 3. Histological sections of the planarian $\boldsymbol{G}$. tigrina using the Feulgen reaction technique. A-E: control group; F-G: exposed group to 0.08 mg $\mathrm{L}^{-1}$ of Malathion insecticide; H-J: exposed group to $0.8 \mathrm{mg} \mathrm{L}^{-1}$ of Malathion insecticide. e: epidermis; nc: nerve cords; p: parenchyma; arrows: chromatin marginalization process. Bars: A-J $=100 \mu \mathrm{m}$. 
3E). All of these nuclei were in interphase and did not show any sign of DNA damage.

We did not find changes in the epidermis for the specimens in the group exposed to $0.08 \mathrm{mg} \mathrm{L}^{-1}$ compared to the control group. However, there has been a severe alteration in the muscle tissue, demonstrating tissue disorganization (Fig. 2G). Similarly, the parenchyma was completely disorganized, such that we could barely identify the typical cell types, due to severe loss of their morphological characteristics. We did not observe the gut for this group.

The cell nuclei of the planarians in this treatment group had no response compared to the control group (Fig. 3F-G).

The characteristics of the epidermis of the individuals exposed to $0.8 \mathrm{mg} \mathrm{L}^{-1}$ of Malathion were similar to the control group, though a few exceptions were found for the mucus layer, in which we detected a slight increase, and for the disorganization o muscle tissue (Fig. 2J).

We also found generalized disorganization in the parenchyma, from which there were only cellular debris (Fig. $2 \mathrm{~K}$ ), proliferation of neoblasts and changes in nerve cords. The latter lost their peripheral region with their central region remaining intact (Fig. 2L).

The gastrodermal cells lost their morphological characteristics and their identification was only possible due to their adjacent position to the lumen (Fig. 2M).

We noticed an increase in pyknotic nuclei and peripheral degeneration of the nerve cords for all individuals in this treatment group (Fig. 3H-J).

Our histochemical results found for all groups, organized by tissue/cell, are displayed in Table 1 and can be checked in Figures 4 and 5.

\section{DISCUSSION}

Although we could not directly observe either morphallaxis (migration of differentiated cells) or epimorphosis (proliferation of undifferentiated cells), our SEM samples had patterns pointing out to such processes. Thus, we inferred that morphallaxis occurs manly in the central region and epimorphosis most likely occurs crosswise. An extensive discussion on this issue is presented by Reddien \& Sánchez Alvarado (2004), although they have applied light microscopy techniques.

Our SEM data obtained for the treatment groups showed morphological differences when compared to the control group. This happened in all treated individuals, particularly in the region of the blastema. Furthermore, the epidermis of treated individuals had an increase both in number and in size of pores and complete absence of cilia in the ventral region.

Such changes for both groups exposed to concentrations of Malathion have possibly occurred due to: (i) the insecticide could have induced an increase in the production of mucus, which caused a dilation of the pores, since planarian mucus has immunological properties, further aiding the regenerative process; (ii) the product altered the cell division process, therefore interposing the development of blastema; or (iii) the chemical has promoted cell death in migration process, thereby interfering in the organism regeneration.

We observed the presence of several types of differentiated cells in the histological results for the control group, distributed among tissues. These data are corroborated by the studies of Baguñà \& Romero (1981) and of Bueno et al. (1997), who have reported the presence of these same cells in planarians. Although we did detect neoblasts in non-injured tissues (i.e., outside of the blastema), we could not distinguish between the two types of these pluripotent cells described by Tiras \& Aslanidi (2016) for G. tigrina.

It is noteworthy that, for every technique we applied in this study, the exposed groups to the insecticide Malathion showed severe tissue changes compared to control group, indicating a high degree of impairment that this product promotes in exposed organisms, thereby, reinforcing the property of some insecticides to contaminate the environment (Howard, 1991). We shall discuss some implications of this fact below.

Through the hematoxylin-eosin staining technique, we observed numerous cellular changes for both evaluated concentrations, mostly related to cell death processes, including both extensive cytoplasmic vacuolation and nuclear degradation, which supports our results based on the Feulgen reaction. Although the formation of double-membrane vacuoles is an expected process in planarians under environmental stress, both cytoplasmic and nuclear changes we observed are characteristics of the presence of necrotic process (Zakeri \& Ahuja, 1997; Krysko et al., 2008) caused by the action of Malathion, rather than basal autophagy (González-Estévez \& Saló, 2010). Our data also corroborate the results of Miranda et al. (2008), who observed the development of necrosis by the action of pesticides in a kind of freshwater fish, namely H. malabaricus.

Regarding the histochemical changes in the epidermis, there was a gradual decrease, from the control group to the highest concentration of the insecticide in the markings of total and acid polysaccharides and proteins of rhabdites. Although we observed a significant increase in production of mucus in the concentration of $0.8 \mathrm{mg} \mathrm{L}^{-1}$ of Malathion, protein and polysaccharide compounds showed lower intensity staining when compared to the control group.

On the other hand, we noticed stronger reactions for total proteins in elongated and cuboidal cells with Malathion concentration increase, possibly due to protein synthetization involved in either cell death or cell detoxification -one would expect such effect in a contaminated environment for both processes. Since there was a gradual decrease of the reaction intensity for polysaccharides with the insecticide concentration, there had been a reduction in synthesis activity of substances containing these components.

We observed gradual decrease of polysaccharides in the musculature of individuals, from the control group up to the highest concentration of the tested product. The strong reaction to PAS we observed for the control group 
Table 1. Histochemistry resulsts of the G. tigrina cell types, exposed and non-exposed to Malathion insecticide. AB: Alcian blue technique; BB: bromophenol blue technique; PAS: PAS technique; (+) weak positive reaction; (++) medium positive reaction; (+++) strong positive reaction; (-) negative reaction; \#: not observed.

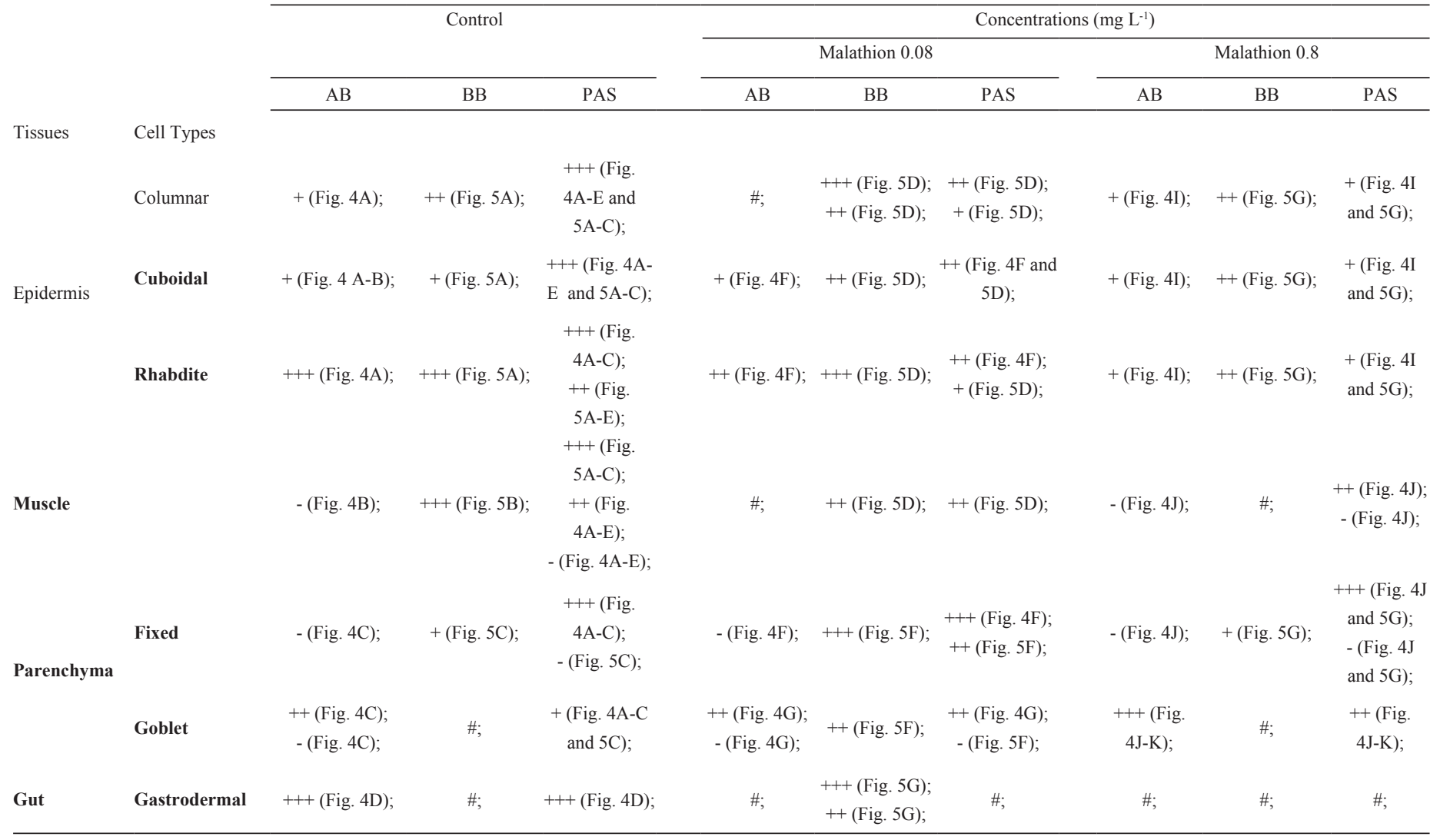

is completely expected, once muscles usually accumulate glycogen (Junqueira \& Carneiro, 2008). Thus, the subsequent decrease in the reaction intensity points out to degenerative effects of substance over the muscle tissue and its cells, which is consistent with the results of Witchley et al. (2013), who found the muscle cells to be partly responsible in triggering planarian regeneration, further explaining the underdeveloped blastema in the treatment groups.

Concerning the parenchyma, we noted significant disorganization as a result of intense vacuolation. Such severe alteration led to difficulties in identifying the different cell types and, despite the degenerative process of this tissue, we could at least observe the proliferation of neoblasts. The few fixed parenchymal cells that we could clearly identify showed an increase in total polysaccharides and protein constituents. We noticed stronger protein staining in the treatment group compared to the control group, a process that can be explained by an increase of enzymatic reactions related to detoxification or to hydrolytic enzymes (acid phosphatases), which, in turn, are connected to the destruction of the cytoplasm (Clarke, 1990; Cummings \& Bowen, 1992; Bowen, 1993; Zakeri et al., 1995; Lockshin \& Zakeri, 1996; Gregorc et al., 1998; Furquim et al., 2008).

The changes in goblet cells, mostly hypertrophy and continuous increase of reaction strength for both total and acid polysaccharides, likely occurred due to the high activity of mucus production, which is responsible for protecting the animal to exogenous agents. Conversely, at lower concentrations, Malathion promoted generalized damage to the digestive tract, including destruction and degenerative changes of the gastrodermis and decrease of brush border cells.

On the one hand, we observed that the lowest concentration of Malathion caused greater cell damage, which may be related to greater cell permeability for lower concentrations. This reasoning has also been used in the studies of Pedro (2008), who applied several different methods to evaluate the genotoxic and mutagenic effects of Fipronil insecticide. On the other hand, the highest concentration of the insecticide we investigated proved to produce greater environmental stress responses.

In either case, one may argue on the relevance of using histological techniques for ecotoxicological assessment in general, since there so many simpler, faster methods available (e.g., enzyme-specific and DNA labeling techniques). The short answer for this line of reasoning lies on the complexity of the field of study itself: there is not a single method neither there is a unique biological model that will thoroughly describe the toxicological effects of a given substance, mixture or environmental sample. Nevertheless, we were specifically interested in which cell types became compromised, possibly impairing planarian regeneration; thus, histology is perhaps the most suitable method to address. 
Finally, in the broadest sense, one could take our methods to apply for risk and environmental quality assessments using G. tigrina, since, to the best of our knowledge, this is a pioneer study to approach Ecotoxicology and histological analysis for said species altogether. In this context, we must mention the work of Brubacher et al. (2014), who developed a protocol using Schmidtea mediterranea, which is another planarian species, popular in regeneration research.

\section{CONCLUSIONS}

By applying different techniques for Scanning Electron Microscopy (SEM) and light microscopy, we found significant changes in the cells and tissues of $G$. tigrina caused by the exposition to the Malathion insecticide. We understand these changes are related to the action of the
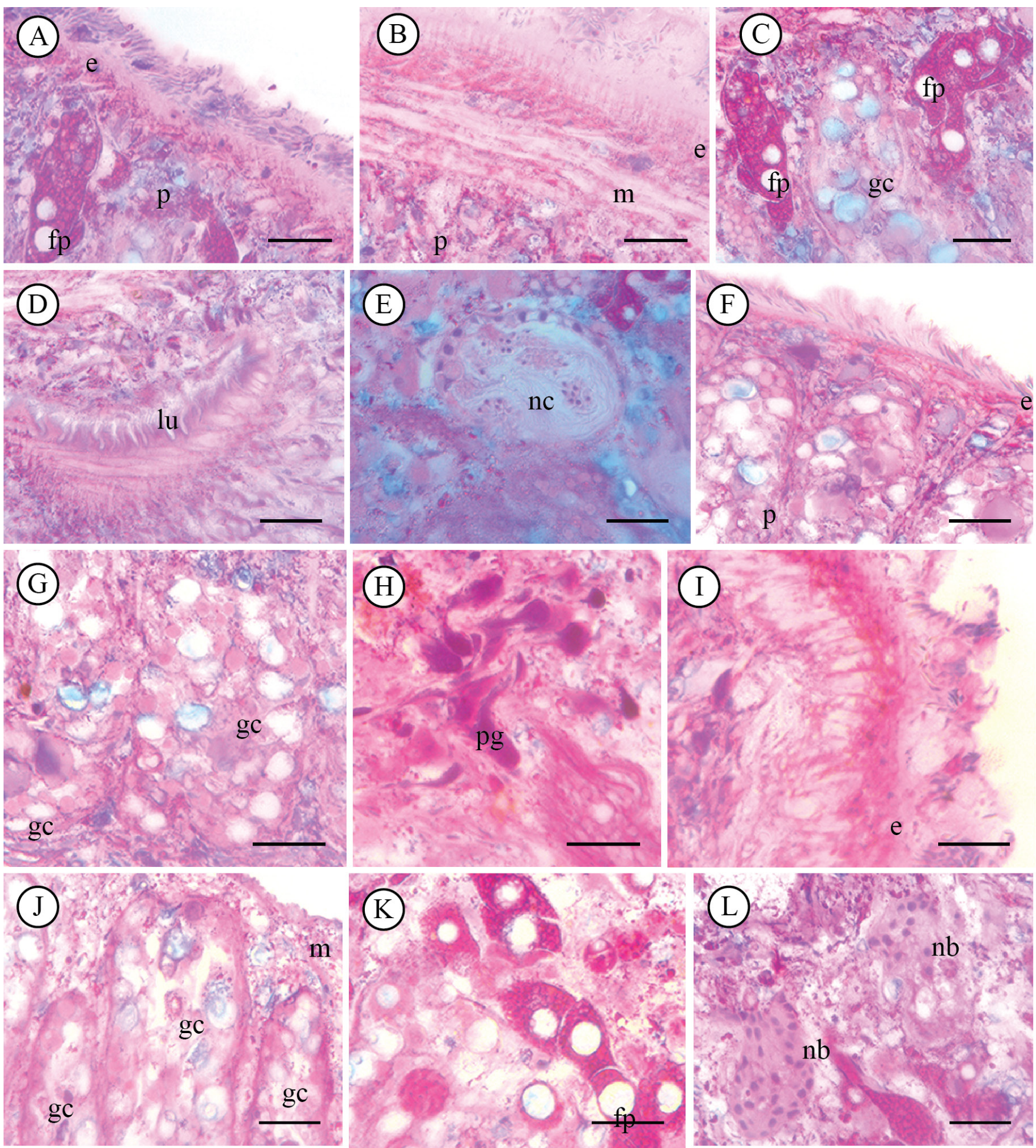

Figure 4. Histological sections of planarians $\boldsymbol{G}$. tigrina stained by PAS/alcian blue conjugate technique. A-E: control group; F-H: exposed group to $0.08 \mathrm{mg} \mathrm{L}^{-1}$ of Malathion insecticide; I-L: exposed group to $0.8 \mathrm{mg} \mathrm{L}^{-1}$ of Malathion insecticide. e: epidermis; gc: goblet cell; lu: lúmen; m: muscles; nc: nerve cords; nb: neoblasts; p: parenchyma; fp: fixed parenchyma cell; pg: pigmentation cell. Bars: A-L = $300 \mu \mathrm{m}$. Note the hypertrophy of goblet cells. 
product and manly refer to: 1 . interference in regenerative capability of planarians; 2 . induction of cell death process characterized by cytoplasmic (formation of extensive vacuolation) and nuclear changes, which resulted in total disruption of tissues, mainly in the parenchyma; 3 . alteration of cellular processes in different tissues, related to the synthesis of glycoprotein components; and 4. stimuli increasing mucus production in the cells of the epidermis (rhabdites) and parenchyma (goblet cells), as a way of protection against the action of the toxic compound. In summary, the action of Malathion insecticide promotes metabolic alterations of G. tigrina, intervening in its regeneration capacity, promoting cellular death and nuclear changes in different tissues.

Using G. tigrina as a biological model, we clearly found that Malathion insecticide produces severe effects on nontarget organisms. Indeed, we noted through cellular changes and deformations of blastema, which is an impairment of reproductive and regenerative capacity of said organism. Our results should raise further awareness of environmental contamination, once disposed chemicals in the environment may suffer successive dilutions, promoting contamination by low concentrations, many of them more bioactive. Therefore, we understand establishing stringent rules against substance abuse is paramount, particularly in countries where this insecticide is widely used.

Although histological and histochemical techniques are information-rich, perhaps it is wise to choose one or two typical markers that will be suitable for future, similar experiments. Thus, we shall recommend the evaluation of fixed parenchyma cells stained by hematoxylin-eosin, since these cells are the most abundant and the easiest to identify, even for an untrained eye; and the fact that the hematoxylineosin staining technique is arguably the most widely available and well-understood histological method, which proved to be useful to identify tissue damage in G. tigrina.
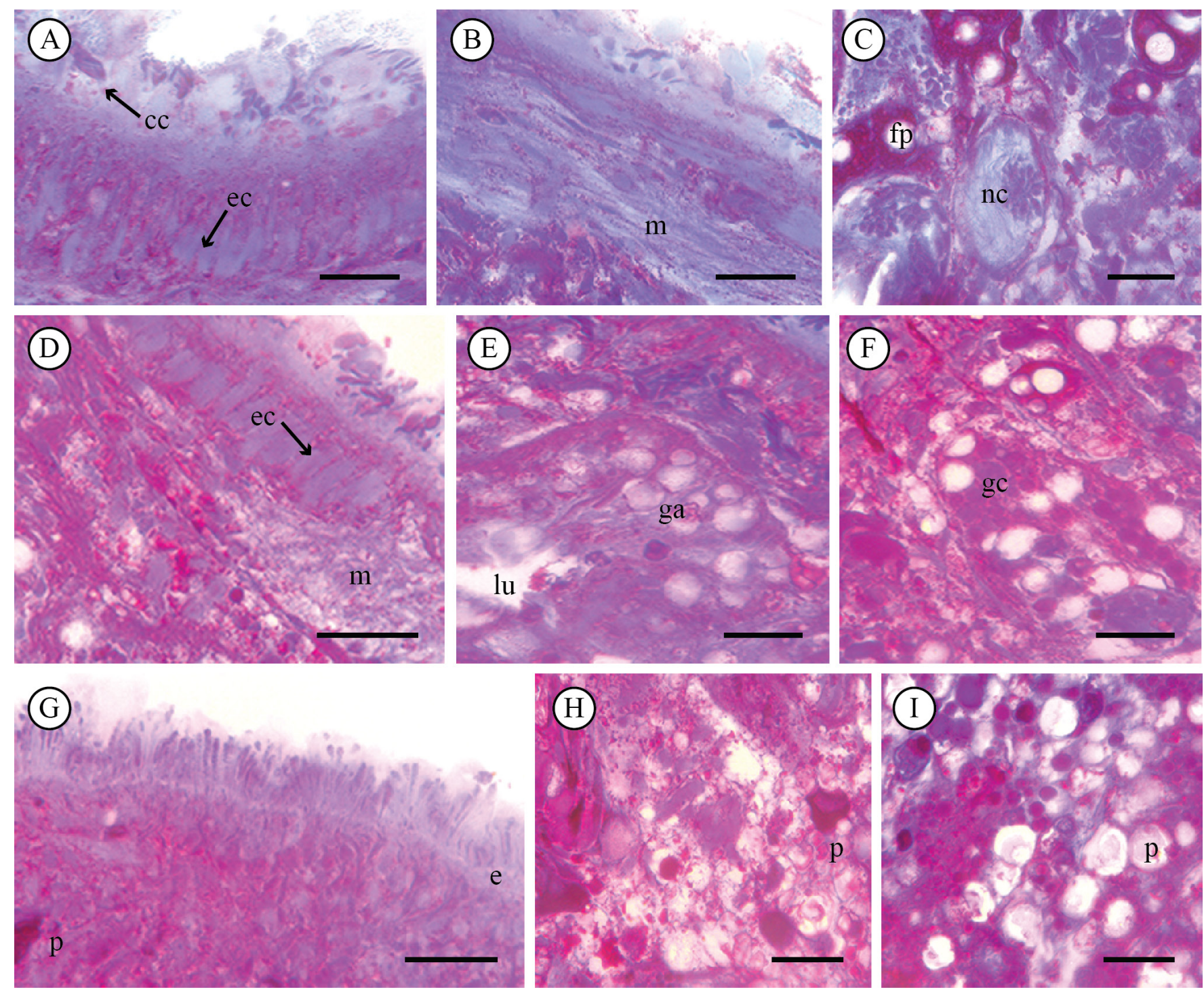

Figure 5. Histological sections of planarians G. tigrina stained by PAS/bromophenol blue conjugate technique. A-C control group; D-F: exposed group to $0.08 \mathrm{mg} \mathrm{L}^{-1}$ of Malathion insecticide; G-I: exposed group to $0.8 \mathrm{mg} \mathrm{L}^{-1}$ of Malathion insecticide. cc: cuboidal cell; ec: elongated cell; e: epidermis; ga: gastrodermal cell; gc: goblet cell; lu: lumen; m: muscles; nc: nerve cords; p: parenchyma; fp: fixed parenchyma cell. Bars: A-I = $300 \mu \mathrm{m}$. Note the hypertrophy of goblet cells. 


\section{ACKNOWLEDGEMENTS}

The authors thank Dr. Dejanira de Franceschi de Angelis and Dr. Cassiana Maria Reganhan Coneglian, for important contributions and the Support Foundation of Sao Paulo State for Scientific Research (FAPESP), processes number 2006/07201-8, for the financial support.

\section{REFERENCES}

ÁLVAREZ-PRESAS， M. \& RIUTORT， M. 2014. Planarian (platyhelminthes, tricladida) diversity and molecular markers: a new view of an old group. Diversity, 6(2): 323-338. http://dx.doi. org/10.3390/d6020323

BAGUÑ̇̀, J. \& ROMERO, R. 1981. Quantitative analysis of cell types during growth, degrowth and regeneration in the planarians Dugesia mediterranea and Dugesia tigrina. Hydrobiologia, 84(1): 181-194.

BOWEN, I.D. 1993. Apoptosis or programmed cell death? . Cell. Biol. Int., 17(4): 365-380.

BRUBACHER, J.L., VIEIRA, A.P. \& NEWMARK, P.A. 2014. Preparation of the planarian Schmidtea mediterranea for highresolution histology and transmission electron microscopy. Nat. Protoc., 9(3): 661-673. http://dx.doi.org/10.1038/nprot.2014.041

BUENO, D., BAGUÑ̀̀, J. \& ROMERO, R. 1997. Cell-, tissue-, and position specific monoclonal antibodies against the planarian Dugesia (Girardia) tigrina. Histochem. Cell. Biol., 107(2): 139149.

CLARKE, P.G.H. 1990. Developmental cell death: morphological diversity and multiple mechanisms. Anat. Embryol., 181(3): 195-213.

COELLO, S.A. 1989. A new staining schedule for formalin-fixed, glycol methacrylate-embedded fish ovaries. J. Fish. Biol., 34(2): 329-330.

CUMMINGS, L.A. \& BOWEN, I.D. 1992. The localization of acid phosphatase as a prelude to cell death in the blow-fly Calliphora erithrocephala. Micron. Microsc. Acta, 23(3): 357-358.

FEULGEN, R. \& ROSSENBECK, H. 1924. Mikroskopischchemischer Nachweis einer Nucleinsäure vom Typus der Thymonucleinsäure und die darauf beruhende elective Färbung von Zellkernen in mikroscopischen Präparaten. Hoppe Seylers. Z. Physiol. Chem., 135: 203-248.

FURQUIM, K.C.S., BECHARA, G.H. \& CAMARGO-MATHIAS, M.I. 2008. Markers of cell death in salivary glands of males of the tick Rhipicephalus sanguineus (Latreille, 1806) (Acari: Ixodidae). Parasitol. Int., 57(3): 396-404. http://dx.doi. org/10.1016/j.parint.2008.04.012

GONZÁLEZ-ESTÉVEZ, C. \& SALÓ, E. 2010. Autophagy and apoptosis in planarians. Apoptosis, 15(3): 279-292. http://dx.doi. org/10.1007/s10495-009-0445-4

GREGORC, A., BOWEN, I.D. \& POGACNIK, A. 1998. Acid phosphatase activity in the midgut of honeybee (Apis mellifera L.) larvae. Apidologie, 29(6): 579-584.

GUECHEVA, T.N., ERDTMANN, B., BENFATO, M.S. \& HENRIQUES, J.A.P. 2003. Stress protein response and catalase activity in freshwater planarian Dugesia (Girardia) schubarti exposed to copper. Ecotox. Environ. Safe., 56(3): 351-357. http://dx.doi.org/10.1016/S0147-6513(02)00065-9

HOWARD, P.H. 1991. Handbook of environmental fate and exposure data for organic chemicals: pesticides. Boca Raton: Lewis Publishers, 684p.

JUNQUEIRA, L.C. \& CARNEIRO, J. 2008. Histologia Básica. Rio de Janeiro: Guanabara Koogan, 524p.

JUNQUEIRA, L.C. \& JUNQUEIRA, L.M.M.S. 1983. Técnicas básicas de citologia e histologia. São Paulo: Editora Santos, $123 \mathrm{p}$.

KNAKIEVICZ, T. 2014. Planarians as invertebrate bioindicators in freshwater environmental quality: the biomarkers approach. Ecotoxicol. Environ. Contam., 9(1): 01-12. http://dx.doi. org/10.5132/eec.2014.01.001

KNAKIEVICZ, T., SILVEIRA, P.A. \& FERREIRA, H.B. 2008. Planarian neoblast micronucleus assay for evaluating genotoxicity. Chemosphere, 72(9): 1267-1273. http://dx.doi. org/10.1016/j.chemosphere.2008.04.058

KRYSKO, D.V., BERGHE, T.V., D'HERDE, K. \& VANDENABEELE, P. 2008. Apoptosis and necrosis: detection, discrimination and phagocytosis. Methods, 44(3): 205-221.

LOCKSHIN, R.A. \& ZAKERI, Z. 1996. The biology of cell death and its relationship to aging. In: Holbrook N., Martin G.R. \& Lockshin R.A., (eds). Cellular aging and cell death. New York: Wiley-Liss, pp. 167-180.

LOWE, J.R., MAHOOL, T.D. \& STAEHLE, M.M. 2015. Ethanol exposure induces a delay in the reacquisition of function during head regeneration in Schmidtea mediterranea. Neurotoxicol. Teratol., 48: 28-32. 10.1016/j.ntt.2015.01.003

MIRANDA, A.L., ROCHE, H., RANDI, M.A.F., MENEZES, M.L. \& OLIVEIRA RIBEIRO, C.A. 2008. Bioaccumulation of chlorinated pesticides and PCBs in the tropical freshwater fish Hoplias malabaricus: histopathological, physiological, and immunological findings. Environ. Int., 34(7): 939-949.

OFOEGBU,P.U., SIMÃO, F.C.P., CRUZ, A., MENDO, S., SOARES, A.M.V.M. \& PESTANA, J.L.T. 2016. Toxicity of tributyltin (TBT) to the freshwater planarian Schmidtea mediterranea. Chemosphere, 148: 61-67. 10.1016/j.chemosphere.2015.12.131

ONGLEY, E.D. 1996. Control of water pollution from agriculture. In: FAO. Irrigation and Drainage Paper, n 55. Rome: FAO. Land and Water Development Div., 101p.

PARSONS, D.W. \& WITT, J.M. 1989. Pesticides in groundwater in the United States of America: a report of a 1988 survey of State Lead agencies. Corvallis: Extension Service of Oregon State University, 106p.

PEDRO, J. 2008. Detecção da citotoxicidade, genotoxicidade e mutagenicidade do inseticida fipronil no organismo teste Allium сера. MSc. Dissertation. Universidade Estadual Paulista "Júlio de Mesquita Filho", Rio Claro, 103 p.

PPDB (Pestcide Properties DataBase). 2016. malathion (Ref: OMS 1). University of Hertfordshire. Available at: http://sitem.herts. ac.uk/aeru/ppdb/en/Reports/421.htm. Last updated: 8 Apr. 2016. Accessed on: 27 Jul. 2016

REDDIEN, P.W. \& SÁNCHEZ ALVARADO, A. 2004. Fundamentals of planarian regeneration. Annu. Rev. Cell. Biol., 20: 725-757.

SALÓ, E. \& AGATA, K. 2012. Planarian regeneration: a classic topic claiming new attention. Int. J. Dev. Biol., 56(1-3): 1-4. http://dx.doi.org/10.1387/ijdb.123495es

SALÓ, E. \& BAGUÑ̇̀, J. 1986. Stimulation of cellular proliferation and differentiation in the intact and regenerating planarian Dugesia tigrina by the neuropeptide substance P. J. Exp. Zool., 237(1): 129-135. http://dx.doi.org/10.1002/jez.1402370117

SÁNCHEZ ALVARADO, A. 2012. Q\&A: what is regeneration, and why look to planarians for answers? BMC Biol., 10: 88

TEHSEEN, W.M., HANSEN, L.G. \& REYNOLDS, H.A. 1992. A scientific basis for proposed quality assurance of a new screening method for tumor-like growths in the planarian, Dugesia dorotocephala. Qual. Assur., 1(3): 217-229.

TIRAS, K.P. \& ASLANIDI, K.B. 2016. Two populations of pluripotent stem cells in planarians Girardia tigrina. Biochem (Mosc) Suppl. Ser. A Membr. Cell. Biol., 10(1): 46-52.

USEPA (United States Environmental Protection Agency). 2009. Reregistration eligibility decision (RED) for Malathion. 
Available at: https://archive.epa.gov/pesticides/reregistration/ web/pdf/malathion-red-revised.pdf. Last updated: 27 May 2009. Accessed on: 27 Jul. 2016

VALA RAGNARSDOTTIR, K. 2000. Environmental fate and toxicology of organophosphate pesticides. J. Geol. Soc. London, 157(4): 859-876. http://dx.doi.org/10.1144/jgs.157.4.859

WILLIAMS, K.A., GREEN, D.W.J. \& PASCOE, D. 1986. Studies on the acute toxicity of pollutants to freshwater macroinvertebrates. 3. Ammonia. Arch. Hydrobiol., 106: 61-70.
WITCHLEY, J.N., MAYER, M., WAGNER, D.E., OWEN, J.H. \& REDDIEN, P.W. 2013. Muscle cells provide instructions for planarian regeneration. Cell. Rep., 4(4): 633-641. 10.1016/j. celrep.2013.07.022

ZAKERI, Z. \& AHUJA, H.S. 1997. Cell death/apoptosis: normal, chemically induced and teratogenic effect. Mutat. Res., 396(12): 149-161.

ZAKERI, Z., BURSCH, W., TENNISWOOD, M. \& LOCKSHIN, R.A. 1995. Cell death: programmed, apoptosis, necrosis, or other? Cell. Death Differ., 2(2): 87-96. 